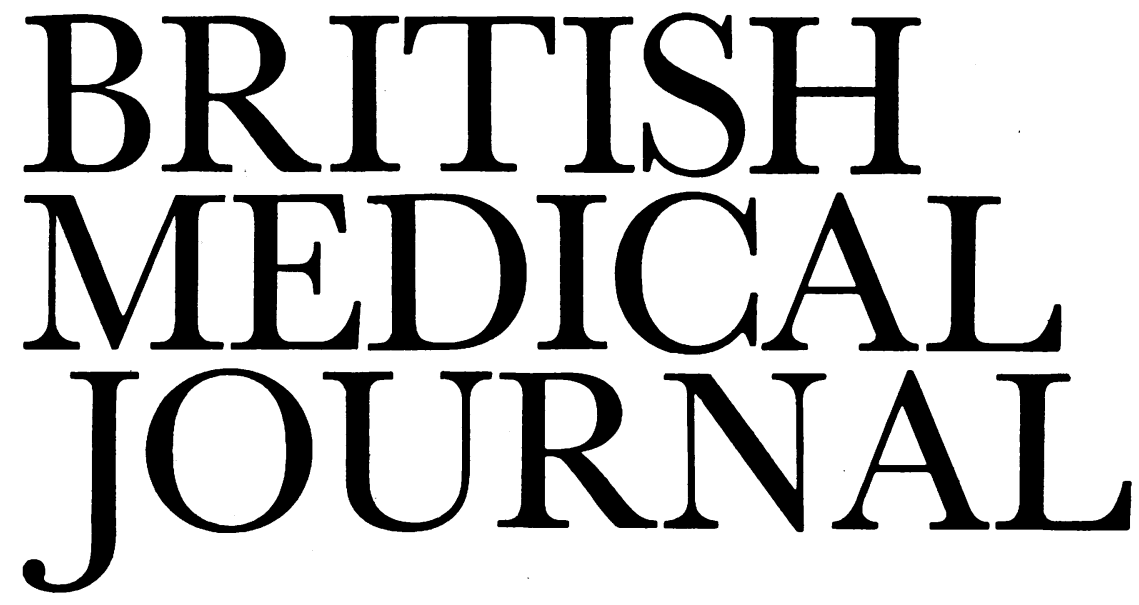

LONDON, SATURDAY 6 JUNE 1987

\title{
Food irradiation
}

Microwave irradiation of food has become accepted as just another form of cooking. "Food irradiation" is, however, usually used to mean treatment with waves a million times shorter $-\gamma$ rays, $x$ rays, or electron beams. This type of irradiation cannot be done in the family kitchen; it requires expensive equipment.

These rays penetrate into a food and produce brief intense ionisation and consequent changes in the largest molecules, notably DNA (including that of micro-organisms). Temperature rises only a little so the food does not look as if it has been cooked with heat. Low doses of ionising radiation (under 1 kilogray (kGy)) will inhibit sprouting of potatoes and onions, delay ripening of some fruits, disinfest cereal grains of insects, and eradicate trichinella in pork. Intermediate doses ( 5 to $10 \mathrm{kGy}$ ) will extend the shelf life of foods by reducing microbial loads and eliminate non-sporing pathogens from spices, chicken, and fish. About $50 \mathrm{kGy}$ are needed for bacterial sterilisation. (The gray is the unit in the Système International d'Unités of absorbed energy as radiation passes through matter and is equal to 1 joule per $\mathrm{kg}$. It has replaced the rad, with $1 \mathrm{kGy}$ equalling 100 kilorads.)

Irradiated food was used for astronauts. In Britain it is subject to government control ${ }^{1}$ and at present permitted only for patients who need sterile diets as part of their treatment ${ }^{2}$ and for preparing the rations of experimental animals. The Joint Expert Committee on Food Irradiation of the Food and Agriculture Organisation, the International Atomic Energy Authority, and the World Health Organisation concluded in 1981 that irradiation of food up to an overall dose of $10 \mathrm{kGy}$ is safe, ${ }^{3}$ and the Codex Alimentarius Commission has accepted this as a food standard. ${ }^{4}$ Irradiation is now permitted for specific foods in 30 countries, ${ }^{5}$ though some of them do not yet have their own processing plants. Last year the United States Food and Drug Administration gave permission for irradiation of fresh fruits and vegetables up to $1 \mathrm{kGy}$ (and of spices at higher doses). ${ }^{67}$

The question of food irradiation is important in all countries because it may carry a lower risk than some of the various chemicals currently used, for example, to delay sprouting of potatoes and onions and to fumigate infested shipments of grain. Until there is international agreement on labelling, small amounts of irradiated foods (like spices) may be moving between countries without indicating their processing history to the consumer.

In Britain the Advisory Committee on Irradiated and Novel Foods reported last year and agreed with the international committee that ionising irradiation of food up to an overall average dose of $10 \mathrm{kGy}$ by $\gamma$ rays or $x$ rays with energies up to $5 \mathrm{MeV}$ or by electrons with energies up to 10 $\mathrm{MeV}$ "presents no toxicological hazard and introduces no special nutritional or microbiological problem." With these doses significant radioactivity cannot be produced in the food. Chemical compounds, radiolytic products, are formed but only in milligram amounts or less, and most are not unique - they occur naturally before or after conventional processing. Review of toxicological evidence does not show that irradiated foods are mutagenic, and laboratory animals fed on irradiated rations have been healthy. Irradiation does not produce dangerous mutant micro-organisms. Losses of nutrients are comparable to those from conventional cooking: vitamin $\mathrm{C}$ and thiamine are reduced; vitamin $\mathrm{E}$ may be more affected; and there is insufficient information about folate. When and if irradiated foods are permitted the British committee advises mandatory inclusion of "irradiated" in the name of the food- "irradiated potatoes" like "pasteurised milk."

When international and several national expert committees agree with our own committee that a process is safe all that is usually required is for the government to set limits and define safe operational procedures. Industry then decides whether it or the consumer can afford the new process and for which products. But there is resistance to food irradiation among ordinary people, who fear (especially after Chernobyl) that the food may be radioactive. Some professional people have also expressed anxiety..$^{8.10}$ There are four main concerns. Firstly, can we safely dismiss the few toxicological studies that appeared to show adverse effects? Discussion focuses ${ }^{810}$ on a report from India ${ }^{11}$ of increased polyploidy in cultured leucocytes from four children with kwashiorkor who were given freshly irradiated wheat (but not others later given stored irradiated wheat). Other scientists in India ${ }^{12}$ and elsewhere think that these experiments were statistically inadequate, and they have been unable to confirm them in large numbers of animals and people. ${ }^{1314}$

VOLUME 294 NO 6585 
The second concern is that irradiation may be used to conceal bacterial contamination of spoilt food without inactivating toxins generated by the earlier bacterial contamination..$^{10}$ But the same need for good hygiene applies equally to other food processes like canning and freezing. Thirdly, there could be a novel pattern of nutrient loss either from the radiation or because irradiated "fresh" foods may be older when they are eaten. The British committee conceded that data on the effects of irradiation on the nutrient content of food are not comprehensive-but they are more extensive than for many accepted methods of food processing. The committee recommended that if irradiation is permitted in Britain the nutrient content of irradiated food and its consumption pattern should be monitored. The fourth worry is that we are unable to recognise that a food has been irradiated. Several laboratories have searched for substances that would enable an analyst to diagnose that a food had been irradiated. It is unlikely that any characteristic substance would be found across all types of foods after low dose irradiation, but different diagnostic substances might yet be found in individual foods.

I see no reason why the government should not permit irradiation of stored winter potatoes and onions at $1 \mathrm{kGy}$ and of listed spices at moderate dosage. This should be coupled with registration and control of all irradiation plants and clear labelling regulations. One problem is that the toxicological evidence is poorly collected, reviewed, and presented. The World Health Organisation is planning a publication, ${ }^{5}$ and I hope that this-or perhaps a government publicationcan assemble the large amount of toxicological work that has been done over the past 30 years in the International Project in the Field of Food Irradiation, in the United States, at Leatherhead in Britain, and in many other countries.

A Stewart Truswell Professor of human nutrition, University of Sydney

Wolfson College,

Oxford OX2 6UD

1 Ministry of Health. Irradiation of food. London: HMSO, 1964. (Committee on Medical and Nutritional Aspects of Food Policy. Report of the working party.)

2 Department of Health and Social Security, Ministry of Agriculture, Fisheries and Food. Report on the safety and wholesomeness of irradiated foods by the advisory committee on irradiated and novel the safely and wholesomeness of

3 Food and Agriculture Organisation, International Atomic Energy Authority, World Health Organisation. Wholesomeness of irradiated food. Geneva: WHO, 1981. (WHO Technical Report Series No 659.)

4 Codex Alimentarius Commission. Codex general standard for irradiated foods and recommended international code of practice for the operation of radiation facilities used in the treatment of fonds. Vol 15, edition 1. Rome: CAC, 1984.

5 World Health Organisation. Food irradiation. Geneva: WHO, 1987. (In Point of Fact No 40.)

6 Kader AA. Potential applications of ionizing radiation in postharvest handling of fresh fruits and vegetables. Food Technology 1986;40:117-21.

7 United States Department of Health and Human Services, Food and Drug Administration. Irradiation in the production, processing and handling of food; final rule. Washington DC: US Government Printing Office, 1986. (FDA 21: CFR Part 179. Federal Register 18 April 51 No 75 .)

8 Anonymous. More research into safety of irradiated food urged. [News.] BMA News Review 1987 April:11.

9 British Medical Association, Board of Science and Education. Irradiation of foodstuffs. London: BMA, 1987.

10 Webb T, Lang T. Food irradiation: the facts. Wellingborough, Northants: Thorsons, 1987.

11 Bhaskaram C, Sadasivan G. Effects of feeding irradiated wheat to malnourished children. Am $\mathcal{J}$ Clin Nutr 1975;28:130-5.

12 Kesavan PC. Indirect effects of radiation in relation to food: facts and fallacies. Fournal of Nuclear and Agricultural Biology 1978;7:93-7.

13 Brynjolfsson A. Wholesomeness of irradiated foods: a review. fournal of Food Safety 1985;7 $107-26$.

14 Food and Agriculture Organisation, International Atomic Energy Authority. Results of feeding trials of irradiated diets in human volunteers: summary of the Chinese studies. Rome: FAO, 1986. (Results reported at a seminar for Asia and the Pacific on the practical application of food irradiation, Shanghai, People's Republic of China, April 1986.)

\section{The wasted opportunity of the election}

Sir Bryan Thwaites, a professor of mathematics and chairman of Wessex Regional Health Authority, believes that the British public is sophisticated enough to recognise that the National Health Service cannot do everything that is medically possible and that therefore bounds and limits need to be set. ${ }^{1}$ The politicians fighting the election clearly do not agree. Most of the election debate has been about how much the various parties have spent or will spend, not about how to spend the money and what to spend it on. The time has clearly come to sit on the ground and talk not of the death of the NHS but of how to square exponentially increasing demand with necessarily limited resources. This was one of the themes of a recent conference at the Royal College of Physicians, reported by Dr Tony Delamothe (p 1440), and Sir Bryan in his foundation lecture last week to the University of Southampton Institute of Health Policy Studies tackled this most painful of subjects head on.

He was not the first by any means to recognise the expanding gap between what might be done and what is done. A BMA report of 1970 said: "The NHS has never since the early years been able to fully cope with the rising demands that it, and the parallel development of new methods of treatment, were responsible for stimulating." It has been fashionable for some time to laugh at the naivety of the belief of the NHS's architects that the new service could quickly mop up bad health and then cheaply maintain good health. Yet the current refusal of politicians to articulate in public what they know in private about the profound limitations of what can be afforded by either a taxation or an insurance based health service is to give the public debate an aura of fantasy not so different from that surrounding the birth of the NHS.

Sir Bryan used his mathematical background and the data supplied to him by his officers in Wessex to calculate that "expectations" are rising by $5 \%$ a year: "If capital and revenue were rolled up together it seems that we [in Wessex] could absorb 5\% more each year over the next five years without running any risk of criticism for waste or extravagance." He identified many factors that are fuelling this exponential increase in demand: public awareness of what can be provided; no charge at the point of delivery; lowered tolerance of discomfort; advances in medical knowledge leading to more complex treatments for more conditions; technological advances leading to diagnoses that would not otherwise have been made (he noted, in passing, that rates of change in microelectronics carry with them demands for capital replacement at unprecedentedly short intervals); demographic trends; more general practitioners, leading to more treatment, combined with more consultants, leading to more research (resulting in what the City calls a "high gearing effect"); and doctors' attitudes and expectations.

Resources cannot, of course, keep up with this demand. Sir Bryan looked back at the rate of growth in the NHS and showed how it was inevitably slowing: between 1957 and 1987 the NHS grew at about 4.5\% a year; between 1977 and 1987 growth slowed to 3.3\%; between 1982 and 1987 it 